\title{
Evaluation of extracted circulating cell free dna concentration by standard nucleospin plasma xs (NS) kit protocol compared to its modified protocol
}

\begin{abstract}
Background: One of the earliest and most common processes for cell-free DNA analysis is its extraction. Our study was to analyze cell-free plasma DNA of prostate cancer (PCA) and of benign prostatic hyperplasia (BPH) patients.

Methods: We extracted circulating cell-free DNA (ccfDNA) from 24 patients' plasma samples (14 PCA; $10 \mathrm{BPH}$ ) by NucleoSpin plasma XS (NS) Kit using the standard kit protocol alongside with a second protocol with some modifications. Subsequently, NanoDrop, PCR and Real-time-PCR were used to evaluate the concentrations of the obtained DNA, respectively.

Results: Concentrations of the extracted cell free DNA with our modified protocol was significantly higher compared to the same DNA samples which were extracted with the company protocol ( $\mathrm{p}$ value $<0.001$ )

Conclusion: We could increase the rate of cell free DNA recovery to a much significant amount which is beneficial for investigators who need to evaluate gene expression in blood rather than not accessible organs and tissues. We recommend the modified protocol for NucleoSpin plasma XS (NS) Kit while the original protocol could not result in appropriate recovery of blood cell free DNA.
\end{abstract}

Keywords: circulating cell-free dna, prostate cancer, modified protocol
Volume 4 Issue 4 - 2017

\section{Maryam Khani,' Farkhondeh Pouresmaeili,'} Reza Mirfakhraie'

'Department of Medical Genetics, Shahid Beheshti University of Medical Sciences, Iran

${ }^{2}$ Infertility and Reproductive Health Research Center (IRHRC) and Department of Medical Genetics, Shahid Beheshti

University of Medical Sciences, Iran

Correspondence: Farkhondeh Pouresmaeili, Infertility and Reproductive Health Research Center (IRHRC) and Department of Medical Genetics, Faculty of Medicine, Shahid Beheshti University of Medical Sciences, Tehran, Iran, Email pouresfar@gmail.com

Received: March 18, 2017 | Published: April II, 2017

\section{Introduction}

To exclude invasive procedures like organ and tissue biopsy to detect changes associated with the disease in clinical approaches and in amniocentesis for prenatal diagnosis of genetic conditions, replacement of non-invasive methods like the use of peripheral blood samples for its content of circulating cell free DNA from fetal source or originating from dead tumor cells, is recommended by previous investigators. Standardization and strengthening easier, more accessible, reliable, low-cost and non-invasive methods meet the needs of the global economy. So far, different kits with manual or semi-automated or fully-automated protocol are used for extracting cell-free-DNA such as QIAamp Circulating Nucleic Acid (Qia), PME free-circulating DNA Extraction Kit (PME), Maxwell RSC ccfDNA Plasma Kit (RSC), EpiQuick Circulating Cell-Free DNA Isolation Kit (EQ), NEXTprep-Mag cfDNA Isolation Kit $\left(\mathrm{NpM}_{\mathrm{V} 1 / 2}\right)$, QuickcfDNA $^{\mathrm{TM}}$ Serum \& Plasma Kit, NucleoSpin plasma XS (NS).

The QiAamp kit is often used for cell free DNA extract, but it is necessary to have a vacuum device to perform the operation. ${ }^{1}$ Nucleospin (NS) is a much cheaper and easy to use kit which is commonly used by postgraduate students. So, to analyze two genes of prostate cancer for the purpose of our study, we used NS kit for extracting cell frees DNA from plasma. The amount of circulating DNA in blood serum is very low and different in people based on their health condition. For example, concentrations in healthy subjects is $20-30 \mathrm{ng} / \mathrm{ml}$ and in men with metastatic prostate cancer is close to $40 \mathrm{ng} / \mathrm{ml}$ and almost $1200 \mathrm{ng} / \mathrm{ml}$ in patients with other types of cancer. ${ }^{2}$ However, when NanoDrop, PCR and Real-time-PCR were used to evaluate the concentrations of cell free DNA, we noticed that the extracts did not meet our expectation as was written in the kit manual. In order to avoid losing time and not to stop the project, we tried to change the kit protocol to achieve the desirable concentration. Thus, the purpose of the present case report was to provide a new protocol for NS kit which makes it more effective to carry out projects similar to ours.

\section{Case presentation}

In our study we needed to extract cell free DNA from plasma samples taken from patients with prostate cancer, benign prostatic hyperplasia and healthy men. According to NS kit protocol to eliminate contamination with DNA blood cells, we took the blood samples without cell lysis in EDTA tubes $(6 \mathrm{ml})$ and transported on ice from hospital to laboratory in 2 hours. Samples were centrifuged at 3000 rpm for $15 \mathrm{~min}$ at $4^{\circ} \mathrm{C}$. The upper part, the plasma, was isolated from each blood sample and stored at $-20^{\circ} \mathrm{C}$ until use. The cell free DNA was extracted according to the kit manual. ${ }^{3}$ Unfortunately, NanoDrop, PCR and Real-time-PCR showed no visible materials of extracted cell free DNA in the Elute (Table1). Since it was not possible to change the kit for the study, either due to more financial burden or time consuming, we asked NS-company to help us in achieving the expected result. For this purpose, reduction in the elution volume in the kit manual steps 6 and 7, or increase the eluted volume in PCR reactions was necessary, as they recommended. The results were unsatisfactory. Thus we changed numerous steps of the protocol to see whether we 
could get the right concentration. According to our instruction, we warmed the buffers before test to receive a better dilution. To provide a replacement for the vacuum condition of QiaGen, we waited for 10 to 15 minutes before each centrifugation, increased the time of spin, and reduced the Relative Centrifugal Force (RCF). The results of the new protocol are presented in Tables 1,2 and in Figures 1,2.

Table I Comparison between standard protocols with modified protocol at a glance

\begin{tabular}{|c|c|c|}
\hline Our Protocol with Modifications & Original Protocol & Steps \\
\hline $\begin{array}{l}\text {-Warm buffers up to } 40^{\circ} \mathrm{C} 30 \mathrm{~min} \text { before use } \\
\text { (water bath), then shake. } \\
\text {-Warm EB up to } 60^{\circ} \mathrm{C} 10 \mathrm{~min} \text { before use. } \\
\text {-Molten plasma } 8000 \times \mathrm{xg} \text { for } 3 \mathrm{~min} \\
\text {-warm up } 250 \mathrm{\mu l} \text { upper Clear Plasma to } 40^{\circ} \mathrm{C} \text { for } \\
\text { use }\end{array}$ & Use up to $240 \mu \mathrm{l}$ plasma & I. Prepare sample \\
\hline $\begin{array}{l}\text {-Add } 25 \mu \text { l Proteinase } \mathrm{K} \\
\text {-Mix } \\
\text {-Incubate at } 40^{\circ} \mathrm{C} \text { for } 20 \mathrm{~min}\end{array}$ & $\begin{array}{l}\text {-Add } 20 \mu \mathrm{l} \text { Proteinase } \mathrm{K} \\
\text {-Mix } \\
\text {-Incubate at } 37^{\circ} \mathrm{C} \text { for } 10 \mathrm{~min}\end{array}$ & Ia. Optional: Proteinase $\mathrm{K}$ treatment \\
\hline Add $360 \mu \mathrm{l} B B$ & Add $360 \mu \mathrm{lBB}$ & 2.Adjust binding conditions \\
\hline $\begin{array}{l}\text {-Invert tube } 3 X \\
\text {-Vortex 3s } \\
\text {-Spin down briefly }\end{array}$ & $\begin{array}{l}\text {-Invert tube } 3 X \\
\text {-Vortex 3s } \\
\text {-Spin down briefly }\end{array}$ & 3. Mix sample \\
\hline $\begin{array}{l}- \text { Wait } 15 \mathrm{~min} \\
\text {-Load lysate } \\
-1500 \times \mathrm{xg} I \mathrm{~min} \\
-7000 \times \mathrm{xg} 30 \mathrm{~s} \\
- \text { Wait } 10 \mathrm{~min}\end{array}$ & $\begin{array}{l}\text {-Load lysate } \\
-2000 \times g \text { 30s } \\
-11000 \times g 5 s\end{array}$ & 4. Bind DNA \\
\hline $\begin{array}{l}-I^{\text {st }} \text { Wash } 500 \mu \mathrm{lWB} \\
- \text { Wait } 10 \text { min } \\
-7000 \times g \text { I min } \\
-2^{\text {nd } W a s h ~} 250 \mu \mathrm{lWB} \\
- \text { Wait } 10 \text { min } \\
-7000 \times g 5 \mathrm{~min}\end{array}$ & 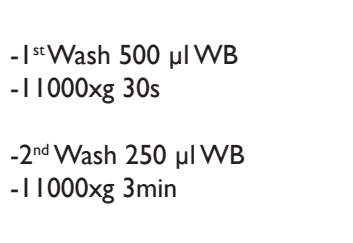 & 5. Wash and dry silica membrane \\
\hline $\begin{array}{l}-25 \mu \mathrm{l} \mathrm{EB} \\
- \text { Wait I5 min } \\
-16000 \times \mathrm{xg} \text { I.5min }\end{array}$ & $\begin{array}{l}-20 \mu \mathrm{l} \text { EB } \\
-I 1000 x g \text { 30s }\end{array}$ & 6. Elute DNA \\
\hline $\begin{array}{l}-80^{\circ} \mathrm{C} 12 \mathrm{~min} \\
\text {-Vaporize all EB } \\
\text {-Add } 15-20 \mu \mathrm{ITEB} \text { or Aquapura }\end{array}$ & $-90^{\circ} \mathrm{C} 8 \mathrm{~min}$ & 7. Removal of residual ethanol \\
\hline
\end{tabular}

BB: Binding Buffer;WB:Wash Buffer; EB: Elution Buffer;TEB:Tris-EDTA Buffer

Table 2 Results of concentration quality between standard protocol and modified protocol

\begin{tabular}{|c|c|c|c|c|}
\hline \multicolumn{4}{|l|}{ Results } & \multirow{2}{*}{ Samples } \\
\hline Real Time PCR & PCR & $\begin{array}{l}\text { Nano Drop } \\
\text { (Concentration) }\end{array}$ & & \\
\hline No pick $(5-6 \mu \mathrm{l})^{*}$ & No band $(5-6 \mu l)^{*}$ & $7-\mid 3 \mathrm{ng} / \mu \mathrm{l}$ & Standard protocol & \multirow{2}{*}{ PCa I- 14} \\
\hline CT: $20-30(2 \mu \mathrm{l})^{*}$ & Band $(2 \mu \mathrm{l})^{*}$ & $60-1 \mid 0 \mathrm{ng} / \mu \mathrm{l}$ & Modify protocol & \\
\hline No pick $(5-6 \mu) *$ & No band $(5-6 \mu \mathrm{l})^{*}$ & $7-10 \mathrm{ng} / \mu \mathrm{l}$ & Standard protocol & \multirow{2}{*}{ BPHI - 10} \\
\hline CT:25-30 $(2 \mu \mathrm{l})^{*}$ & Band $(2 \mu \mathrm{l}) *($ Figure I) & $45-95 \mathrm{ng} / \mu \mathrm{l}$ & Modify protocol & \\
\hline
\end{tabular}

PCa: Prostate Cancer; BPH: Benign Prostatic Hyperplasia; CT: Cycle Threshold; *: Used Elution Volume in PCR reaction (20 $\mu$ l total volume) 
Ladder100_NTC_Ctrl+_BPH1_BPH2_BPH3_BPH4_BPH5

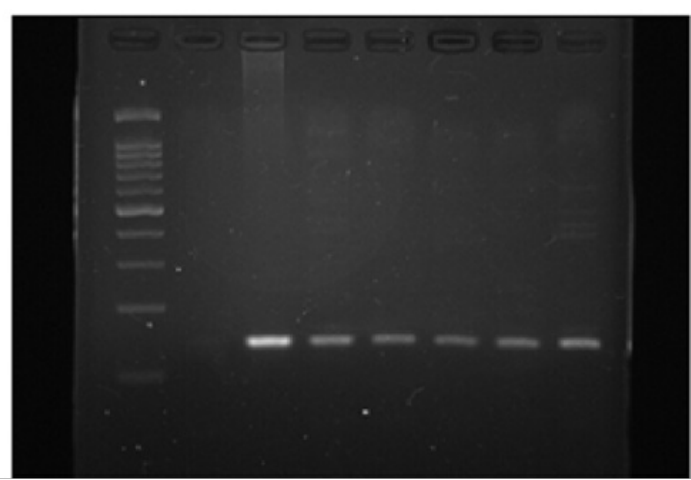

Figure I Quality demonstration of the extracted samples on $2 \%$ agarose gel by modified protocol. BPH: benign prostatic hyperplasia, NTC: Negative control, Ctrl+: lymphocyte DNA, BPHI-5: extracted cell free DNA from 5 samples.

\section{Results}

The first data is related to the concentrations of the standard protocol and the modified protocol using Kolmogorov-Smirnov normality test. The test indicated that the data were normally distributed. To compare

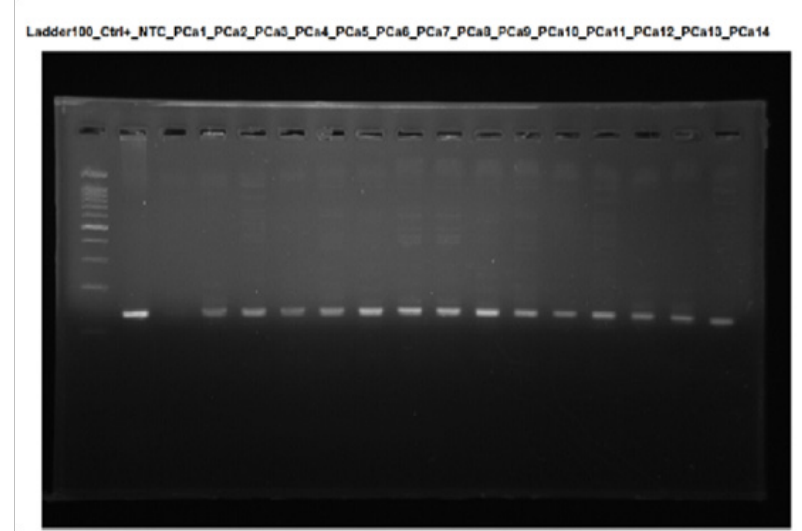

Figure 2 Quality demonstration of the extracted samples on 2\% agarose gel by modified protocol. PCa: prostate cancer, NTC: Negative control, Ctrl+: lymphocyte DNA, PCAI-I4: extracted cell free DNA from I4 samples.

the average concentration of both standard and modified protocols, we used Paired-T-test (Table 3). The test results showed that the mean concentration of the modified protocol was significantly higher than the standard protocol $(70.7, \mathrm{P}$ value $<0.001)$.

Table 3 Results of the extraction protocol comparison by Paired-T-test

\begin{tabular}{|l|l|l|l|l|l|}
\hline P-Value & $\begin{array}{l}\text { Mean Difference } \\
\mathbf{\pm S D}\end{array}$ & SD & $\begin{array}{l}\text { Mean of } \\
\text { Concentration }\end{array}$ & $\begin{array}{l}\text { Number } \\
\text { of } \\
\text { Samples }\end{array}$ & \\
\hline \multirow{2}{*}{$<0.001$} & $70.7 \pm 17.71$ & 3.07 & 9.71 & 24 & Standard protocol \\
\cline { 3 - 6 } & 19.93 & 80.42 & 24 & Modified protocol \\
\hline
\end{tabular}

SD: Standard Deviation

\section{Discussion}

The NS kit is often used for extracting cell-free-DNA from EDTA exposed plasma serum, and bronchial lavage in a range of 50-1000bp. However in our study it did not work with the proposed protocol in the user's manual. Therefore, we made several changes in the entire protocol through which we could get the satisfactory results. Previous researches have shown that the cell free DNA amounts in plasma depends on each individual and his/her health condition such as the kind of disease, cancer or pregnancy. The content of DNA in prostate cancer patients' plasma is less than other cancers. So, a qualified kit should contain fresh and effective reagents besides a well written protocol to provide high amounts and pure expected materials from the samples. However since the kit was effective when the protocol was changed, the only thing that needs to be changed in this kit is the guide.

We could increase the original concentration without decreasing the volume. This article specifically describes a possible method of increasing the rate of cell free DNA recovery as applicable to NucleoSpin plasma XS (NS) Kit. The modified protocol may prove a value to other researchers facing similar ccfDNA recovery yield problems although this is a single center experience report and its applicability needs to be replicated. We recommend the investigators to follow our protocol for NS kits instead of the original kit to experience the advantageous results of our protocol. There are questions arising from our achievements for future studies. Can these modifications be performed on buffers of other extraction kits where the same separation steps and filtration are applied? The impact of these changes can be examined for cell free DNA studies when using blood samples and other extraction kits.

\section{Acknowledgment}

We present our sincere thanks to Dr Saeed Zarein-Dolab (English Language Department, SBMU) for reading the manuscript and Dr znollah Azargashb (Social Medicine Department, SBMU) for his precise statistical advice.

\section{References}

1. http://www.calpoly.edu/ bio/ubl/protocols_files/qiaalu.pdf

2. Rouprêt M, Hupertan V, Catto JW, et al. Promoter hypermethylation in circulating blood cells identifies prostate cancer progression. Int $J$ Cancer. 2008;122(4):952-956.

3. http://www.mn-net.com/portals/8/attachments/redakteure_bio/ protocols/genomic\%20dna/um_circdnaplasma_nsxs.pdf 